Article

\title{
Social Capital and Value Co-Creation: The Case of a Polish Car Sharing Company
}

\author{
Grzegorz Tchorek ${ }^{1, *}$, Michał Brzozowski ${ }^{2}$ (), Katarzyna Dziewanowska ${ }^{1}$, Agnieszka Allen ${ }^{1}$, \\ Waldemar Kozioł ${ }^{1}$, Michał Kurtyka ${ }^{1}$ and Filip Targowski ${ }^{1}$ \\ 1 Centre for Research in Energy Transformation, Mobility and Climate Change, Faculty of Management, \\ University of Warsaw, Szturmowa 1/3, 02-678 Warsaw, Poland; kdziewanowska@wz.uw.edu.pl (K.D.); \\ awysokinska@wz.uw.edu.pl (A.A.); wkoziol@wz.uw.edu.pl (W.K.); michal.kurtyka@gmail.com (M.K.); \\ ftargowski@wz.uw.edu.pl (F.T.) \\ 2 Faculty of Economic Sciences, University of Warsaw, Długa Street 44/50, 00-241 Warsaw, Poland; \\ brzozowski@wne.uw.edu.pl \\ * Correspondence: tchorek@wz.uw.edu.pl; Tel.: +48-22-55-34-111
}

Received: 13 April 2020; Accepted: 5 June 2020; Published: 9 June 2020

check for updates

\begin{abstract}
Based on the original and unique data collected from 1000 users of PANEK CarSharing in Poland (the biggest car sharing company in Warsaw), we explored the roles of social trust and social capital in stipulating the process of value co-creation, understood as the ability to share information (engage in dialogue) with other users and the system operator. Our results indicate that particular trust has a more positive influence on the dialogue between users and the operator than general trust. This means that the higher social capital that can be established among a relatively coherent group of people with similar interests and common goals is more important than the general trust arising from our assumption that all people can be trusted, even if we do not know them. Moreover, those customers who see a shared car as a substitute for private ownership as well as those who are more environmentally aware, reveal greater propensity to share information. An important incentive for information sharing is its positive influence on improving the quality of a car sharing system.
\end{abstract}

Keywords: sharing economy; car sharing; particular trust; social capital; value co-creation

\section{Introduction}

This research owes its inspiration to the growth in environmental pollution in large cities and the resulting higher mortality rates [1]. Shared mobility and car sharing are seen as elements of urban sustainability [2], because the existing model of car usage seems to be inefficient from the perspective of resource allocation and urban logistics. For over $95 \%$ of its life cycle, a (private) vehicle is not used but only occupies space [3].

For these reasons, we regard shared mobility and car sharing as a potentially important element of the response needed to the problems of congestion and smog [4]. A crucial factor that we would expect to influence the propensity to use car sharing services and to be involved in value co-creation processes is the level of social capital and especially, particular social trust [5].

Social capital and social trust are issues that are being discussed more and more frequently in the sharing economy literature, but an in-depth understanding of their role is still limited [5-8]. We know that a sharing economy focuses stakeholders, their collective action, and coordination, towards common goals [5]. Moreover, the social component of the sharing economy shifts the consumers' attention away from ownership and towards utilization, and this demands different forms of interaction and communication. We assume that social trust is a determinant of information sharing and identify it with Dialogue, which is one of the elements of the DART model (dialogue, access, risk assessment, and 
transparency). We focus on Dialogue as an important aspect of sharing activity and as a crucial and fundamental part of the value co-creation process [9]. In a broad sense, we see information sharing as a very important feature in the operation of an efficient sharing economy, which is not present (or is present to a far lesser extent) if a traditional (even eco-friendly) good is bought for exclusive individual use.

The shift from ownership to service use in general, and to car sharing in particular, was recognized more than two decades ago as a way to promote sustainable development [10]. Car sharing is a user-led innovation, which requires, both in its early development and in the diffusion phases, the direct influence of customers on the user-relevant characteristics of the new technology [11].

The aim of this paper is to assess the influence of social trust on customers' involvement in information sharing as part of the phenomenon of value co-creation through car sharing. The focus is directed to social trust as a determinant of the dialogue between a car sharing company in Poland and its customers.

We hypothesize (H1) that particular trust is crucial in developing dialogue between the car sharing operator and the service users. The knowledge about the car sharing is valuable only for the provider and for the other users of the service, meaning that trust in people of your own kind is a key determinant in information sharing. Uslaner describes particular trust as 'faith only in your own kind' [12]. A corollary hypothesis (H2) states that general social trust, which extends to people as a whole, has no effect on the willingness of customers to share information.

A large body of research papers on car sharing, social capital, consumers' pro-environmental behavior, and the value co-creation have been published in prestigious journals of economics, marketing and management, urban mobility, and transportation. However, only a few of these combine shared mobility, value co-creation, and social capital $[5,13]$. We base our research on a combination of these few strands of literature and thereby hope to contribute to the literature.

First, we extend the literature on the determinants of social capital and information sharing in car sharing. While researchers have acknowledged the role of social trust and social capital in the popularization of a sharing economy, the mechanisms that govern the interactions between shared car users and operators are still not understood in any depth.

Second, we contribute to the literature on the phenomenon of value co-creation (vcc) and information transfer in car sharing. Information sharing is recognized as an important feature of value co-creation, but it has very rarely been investigated empirically in the field of sharing, and especially in shared mobility [13]. We concentrate on Dialogue as part of the DART model, which is a very attractive concept for explaining the phenomenon of value co-creation, but it needs further empirical verification. Moreover, we try to identify the difference in propensity to information sharing with other users and with the sharing platform operator.

Third, we provide new insights into the motivation to share information in the course of car sharing activities. The literature related to car sharing has focused on standard determinants (such as lower total cost of ownership, technological push factor, close substitution to private cars, etc.), whereas we concentrate our attention on factors that influence the propensity of customers to become involved in a dialogue and in value co-creation.

\section{Literature Review}

\subsection{Car Sharing and Sustainable Mobility}

We discuss car sharing in the broad, comprehensive context of the sharing economy, which has the potential to have a stabilizing influence on the economy and the environment [14]. Described as collaborative consumption, the process of sharing access to goods and services with other people is a result of IT popularization, growing consumer awareness, changes in personal preferences ("to use" instead of "to have"), the commercial use of social media, and potential economic benefits $[15,16]$. Collaborative consumption [17,18], value co-creation [9], co-production [19], and prosumption [20] 
are a set of closely related categories contained within the concepts of the sharing economy, the collaborative economy, and the access economy [21].

While environmental issues are not directly at the center of our considerations, it is important to highlight that car sharing as social innovation may be a sustainable solution, especially for cities, when it operates effectively as a part of the local mobility ecosystem. The main argument behind this assumption is that car sharing shifts consumers' attention from ownership to utilization. That is why we claim that even if a shared car fleet is not low or zero emission, its environmental impact will be positive if it leads to lower private car usage [22]. In this sense, car sharing (as well as information sharing) may be seen as pro-environmental behavior by consumers.

Based on scientific research, car sharing makes it possible to replace up to 10 private cars with one shared car, thereby decreasing pollution and "releasing" a proportion of occupied urban areas. It therefore seems to be an important and desirable element of sustainable urban mobility. A review of the literature on American car sharing customers suggests that heavy users give up (sell) their cars (from $5 \%$ to $55 \%$ of users), and some (from $7 \%$ to $70 \%$ ) refrain from buying one [23]. The results of research in the German market indicate that a vehicle used for city car sharing can replace up to 20 individual cars and reduces the number of owned cars by $62 \%$, with the substitution ratio seeming to be even higher in the case of station- based systems [24]. Based on research in the Netherlands, it has been confirmed that car sharing reduces car journeys by approximately $15-20 \%$ and that car ownership per household drops from 1.12 to 0.76 [25]. A comparison of existing research studies is presented in the following Table 1 [26].

Table 1. Studies showing the impact of car sharing on car ownership.

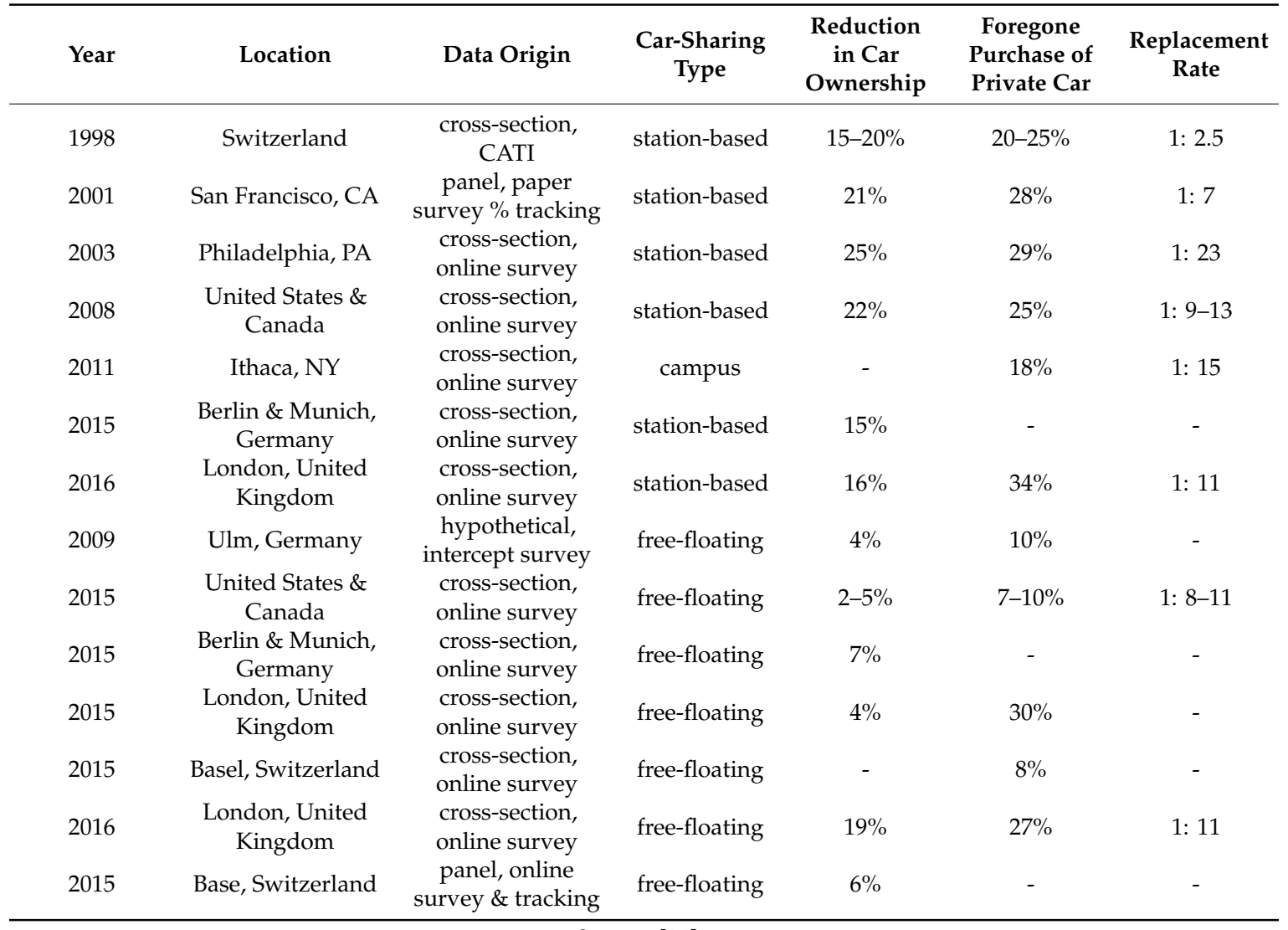

Source: [26].

Unfortunately, despite years of experience in operating car sharing systems, which had their inception at the beginning of the 2000s, car sharing services do not yet play an important part in urban mobility even in a friendly regulatory environment that is supported by incentives. Cities that promote 
car sharing still have problems with large numbers of privately owned cars that occupy a large part of the urban area. In London, which is said to be an example for models of well-implemented shared mobility, among 11 car-sharing operators, there are fewer than 200,000 registered users (2016 data).

Although generally, car-sharing mobility is infrequently used in cities, Germany is a very promising case. Here, a long tradition of shared mobility (initially in the form of cooperatives), the important role of station-based car sharing (that increases the reliability and predictability of the service and encourages people to give up their private cars), the regulations, the involvement of many local partners, as well as the eco-friendly habits of German citizens have all served to increase the use of car sharing [24].

Unfortunately, the German market is the exception rather than the rule, and disappointing experiences in the popularization of car sharing force us to recall our initial research question: What kind of determinants will increase the propensity to develop efficient shared mobility systems? In particular, we are interested to discover whether social capital may influence information sharing among users and operators and thus indirectly open the way to promote acceptance and increase the usefulness of the whole system.

\subsection{Social Capital, Information and Car Sharing, Value Co-Creation}

Social capital and social trust are expressed in the sharing economy literature as important driving forces for collaborative consumption, but an in-depth recognition of their role is still in its early stages [5-8]. We identified at least two research gaps in the literature in the area of social capital and car sharing customer behavior. The first one concerns an examination of relations between social capital and car sharing, and the second is associated with investigating the relations between social capital and value co-creation. Our literature review suggests that empirical exploration in this field is still weak.

A broad definition of the theoretical roots of car sharing would need to include environmental economics, institutional economics, and neo-institutional economics $[27,28]$. The problem is that car sharing is associated with economics when it is seen as a consumption phenomenon. When it relates to consumer behavior, it will be attributed to marketing. When it is considered in the context of value co-creation, it will correspond to management issues.

According to social capital theory, a high level of trust reduces transaction costs between stakeholders and thus increases the efficiency of social and economic systems. A lower cost, which is at the center of transaction cost theory, results from collective actions, shared norms, efficient instruments for finding consensus, and less opportunistic behavior, inter alia [29,30].

The ability to operate in an environment of trust increases the intensity of interactions and the value of social assets (e.g., network relations) as well as innovative activity. Therefore, a high level of social trust (social capital) should increase the intensity of the interactions between operators and users of car sharing services, leading to service optimization based on common goals, while also increasing the social, economic, and environmental benefits of shared mobility [5]. We can also expect that a sharing economy (and shared mobility) should concentrate stakeholders through their collective action and coordination. Higher social capital and social trust should not only improve interactions within the car sharing ecosystem, but also encourage more people to use shared services, having in mind the positive influence of car sharing on the environment and congestion.

Based on the above considerations, we assume a positive relation between social capital and information sharing (dialogue), which is recognized as an important feature and prerequisite of value co-creation $[13,31]$. Dialogue entails an engagement and interaction that stipulates sharing of experiences between users [32,33]. A deeper and more interactive dialogue between customers regarding their experiences will offer greater value in co-creation potential through this information sharing [32].

Sharing data and experiences appears to be crucial in the daily operation of car sharing because the efficient functioning of the system demands the exchange of a lot of data between operators and customers and between users. The key data relate to a car's location, its availability, its current state 
of fuel, as well as customer actions (refueling, cleaning, parking, etc.). A well-organized data flow seems to be one of the crucial prerequisites for effective functioning of a car sharing system because here communication plays a much more important role than in the case of "traditional" services. Car sharing operators need and often demand information and feedback from users (received mostly through an app). This information includes the location of the car, its condition (e.g., range), feedback from the user about whether the car meets expected standards and agreed conditions, but it also includes information that is shared voluntarily by users (e.g., ideas about service improvement).

These characteristics of communication between the customers in a car sharing ecosystem match the concept of the active participation of users in creating value. Hence, the value co-creation model seems to be promising in investigating, evaluating, and improving the information sharing process in car sharing services (Figure 1).

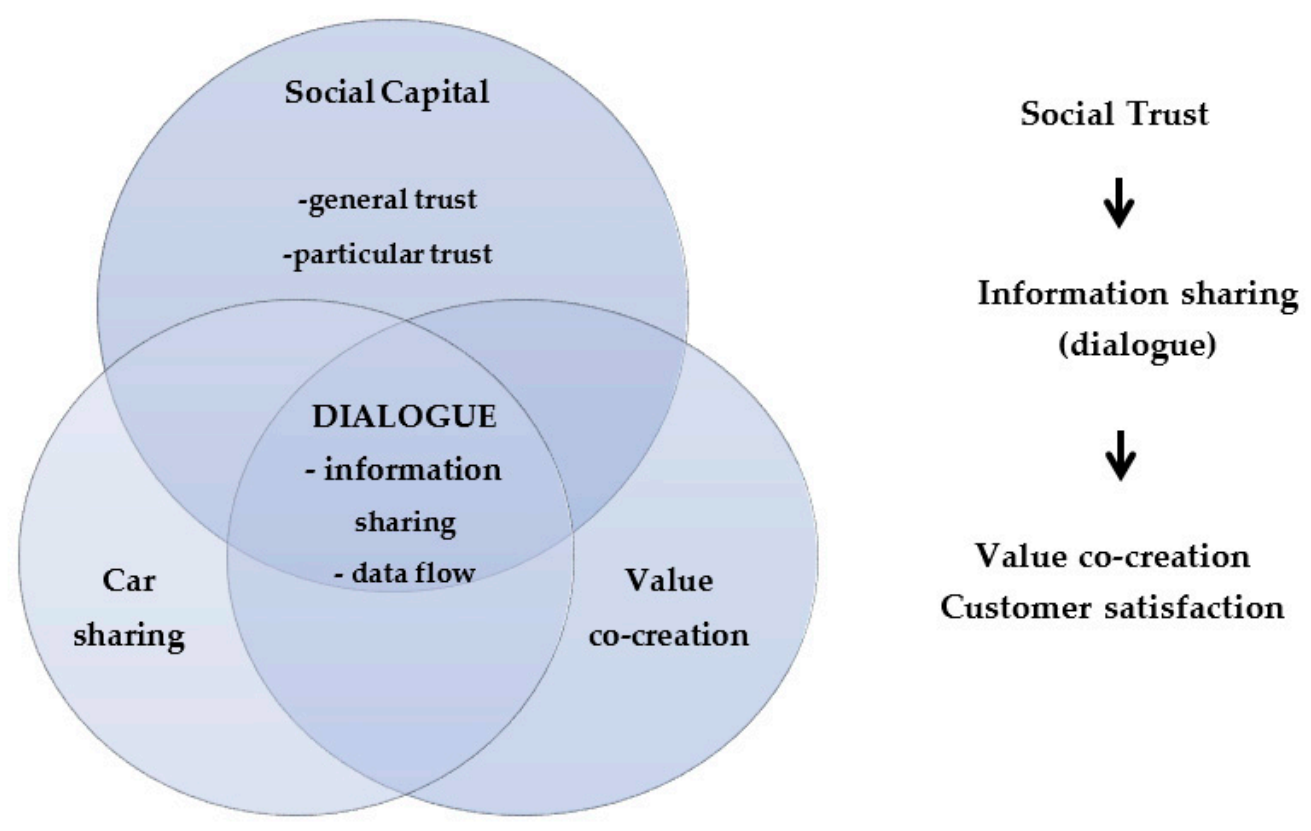

Figure 1. Car sharing, social capital, and value co-creation.

Although the aspects of social capital are fairly often analyzed for sharing economy businesses [5,34,35], very few studies that focus on this concept relate it to car sharing. Initial results indicate the importance of trust and community belonging when choosing a shared mobility service, and these factors are possibly even higher in car sharing than in other areas of the sharing economy.

One of the available studies was conducted in Austria in 2015 with samples of 186 and 328 consumers and trust was measured by a series of questions using vignettes and a seven-point Likert-type scale [36]. The results suggest that reason-based trust (individuals trust the other party if they find that they pursue similar goals, act benevolently, and have like motivation) in other users is higher in self-regulated communities (such as in peer-to-peer or collaborative modes of car sharing) than when a company provides a car sharing service. Another study on trust building in a car sharing platform was conducted in 2018 in China with a sample of 307 customers [37]. The authors developed a research model to examine the effects of four institution-based mechanisms involving: (1) Payment security, (2) driver certification, (3) surge pricing, and (4) feedback on customers' trust building and continued intention regarding the car sharing service. All items were measured using a seven-point Likert-type scale ranging from "strongly disagree" (1) to "strongly agree" (7). The study suggests that, of the measured factors, the feedback mechanism is the most significant in building customers' trust (followed by surge pricing, driver certification, payment security). The study proves that customers' trust in the car sharing platform is beneficial in promoting their intention to continue. This statement is confirmed by research conducted in Germany among the users of car sharing service car2go and 
the online community accommodation marketplace, Airbnb [38]. For both these services, trust was revealed to be an essential determinant of satisfaction with the service and a factor that increased readiness to choose the sharing option again. Interestingly, the comparison between the $\mathrm{B} 2 \mathrm{C}$ car sharing and the $\mathrm{C} 2 \mathrm{C}$ Airbnb sharing economy services showed that service quality aspects and a sense of community belonging played a far more significant role in car sharing.

The analysis of the concepts of value co-creation and social capital from the perspective of car sharing, accompanied by relatively weak empirical investigation, prompts the conclusion that measuring, analyzing, and understanding the interaction between the participants of car sharing services (sharing information) would seem to be a crucial aspect of service optimization, improvement and popularization.

\subsubsection{Is Poland Catching up in Terms of Social Trust?}

As an emerging market, the issue of social capital is particularly important in Poland, which, since 1989 , has been undergoing a process of social and economic transformation. This issue is more fully described by Kolankiewicz and Chloupkova and by Svendsen and Svendsen, inter alia, who show the extent to which social trust was eroded under communism in Poland [39,40]. Comparative studies presented in the second of these papers are particularly important from the perspective of building social capital. These results indicate that prior to Poland's accession to the European Union in 2004, the level of trust in Poland was significantly lower than in other countries, and that this is still the situation today. When we compare Poland with Denmark (which is the country showing the highest level of social capital in many rankings), a huge gap can be recognized. Using three measures: (1) Membership of voluntary organizations, (2) trust, and (3) civic participation, Paldam in 2002 and Hjollund et al. in 2001 indicated that two decades ago, there was a lower level of membership of voluntary organizations in Poland ( $88 \%$ of those surveyed in Poland did not belong to any organization, compared to $23.4 \%$ in Denmark) and a lower level of standard generalized trust (20.1\% in Poland compared to $73.9 \%$ in Denmark) or civic participation (17.1\% in Poland compared to 34.7\% in Denmark) [41,42].

Based on current data available in the World Values Survey Wave 6, Poland can be classified as a country with a relatively low level of general social trust (trust in other people) but an important role for family relations. Can this lower level of social capital in Poland relative to western European countries have an impact on the development of a sharing economy? Has the situation changed 30 years after the end of communism, and is the level of social capital now sufficient to support car sharing services in Poland?

Our research responds to these questions by focusing on a cohort of young people who have a far more active attitude in relation to using everyday communication tools. Older people are less sensitive to environmental issues, less willing to share opinions, and less willing to use modern communication channels- the Internet and social media. Our study therefore involves a population of younger, well-educated professionals from a large city where, due to social change, social trust should be greater and attitudes towards car and information sharing may be more flexible.

\subsubsection{Social Capital Types}

For researchers, measuring social capital and trust is problematic; the empirical evidence is still in its early stages and is based on a small number of surveys [43]. The challenge when trying to operationalize social trust and social capital is that they are interrelated but elusive concepts that are highly sensitive to how they are defined and measured.

While social capital, as an idea, is widely recognized, its different types may favor the sharing economy in different ways. Bonding (exclusive) capital, which dominates relations within close and rather small groups of people (such as family), might have an exclusive character and pose an obstacle to interacting with broad (unknown) groups of people [44,45]. Becoming a member of the sharing society can pose problems, but when it has already happened, it can help to build trust among the population of users. Bridging (inclusive) social capital may generate trustworthy relations among 
individuals and groups that may not even have face-to-face relations [46]. While the above kinds of social relations tend to be complementary, we can assume that bridging social capital is crucial (a prerequisite) for sharing, at least as a general incentive to share. More advanced bridging social capital should imply a better understanding of collective interests, which is of the greatest importance when addressing sharing and shared mobility issues. Bonding relations might have a positive influence on building a sense of community in an existing sharing system, for example, when we want to highlight the exclusive character of the platform and the community of users.

The above distinction between two forms of social capital corresponds to the two forms of social trust that should be recognized, measured, and investigated: Particular trust and general social trust [47]. Particular trust means that trust can only be placed in a specific group of people whom we know and have experience of (family, friends, professional associates, neighbors) or at least have information about [48]. In the case of general trust, we trust people in general, everyone to the same extent regardless of who they are or how well we know them [49,50]. The second type of trust is broader and reflects a more general attitude towards people and strangers.

\subsection{Value Co-Creation and Its Dimensions}

In economics and the management sciences, economic value has been at the center of practitioners' and theoreticians' attention for several decades. Due to the popularity of the concept, there are multiple definitions and conceptualizations with the result that value is one of the most misused terms [51]. Research on value can be classified as one of two approaches: The traditional or the modern [52]. The traditional stream of research offers five value perspectives: Utility, economic worth, perceived satisfaction, net benefit, and the means towards a goal. This approach promotes the view that value is embedded and distributed in tangible things. In contrast, the modern approach started in the late 1980s with a seminal work by Holbrook and Hirschmann on the experiential aspects of consumption [53], and it resulted in the view that value is formed through customer experiences [54,55].

The modern approach postulates a different role for customers who become active value creators and are equal partners in companies [56]. This notion of value has gained momentum with the development of the service-dominant logic (SDL), a recent concept aspiring to become the philosophical foundation of service science $[57,58]$. SDL emphasizes service (not products and services) as the basis of all exchange on the market. This market exchange involves multiple actors or stakeholders who interact with each other within a particular service ecosystem, integrating resources and co-creating value $[58,59]$. Here, value is defined broadly as a change in the viability (wellbeing) of a system [31]. According to SDL, the firm cannot create value on its own, it can only offer a proposition of value, which will be subjectively determined by the consumer via the experience of the co-creation process [60]. Value co-creation is characterized by interactive cooperation and takes place within a service ecosystem [59] that comprises multiple actors and focuses on their interaction, interdependencies, adaptations, and evolution.

A number of attempts have been made to conceptualize value co-creation and its underlying processes. While some researchers focus on a certain type of actor (e.g., the consumer) [61] or analyze components of the process [62], others propose a holistic view on the co-creation phenomenon [63]. Many of these conceptualizations remain purely theoretical and have never been tested empirically. However, the DART model, proposed by Prahald and Ramaswamy, is one of the few that have been empirically verified $[9,64,65]$. The model identifies four building blocks of interaction between the customers and the firm, which lead to value co-creation: Dialogue, access, risk assessment, and transparency.

Dialogue, as the main building block, means engagement and interactivity as well as a propensity to act. All participants in the dialogue are equal, and they share empathic understanding built around consumer experiences. Engagement in the dialogue results in open communication and learning on both sides, which leads to the creation and maintenance of a loyal community. In order for dialogue to 
take place effectively, certain conditions have to be met; namely, there is a focus on issues of interest to both parties and clear rules of engagement (Figure 2).

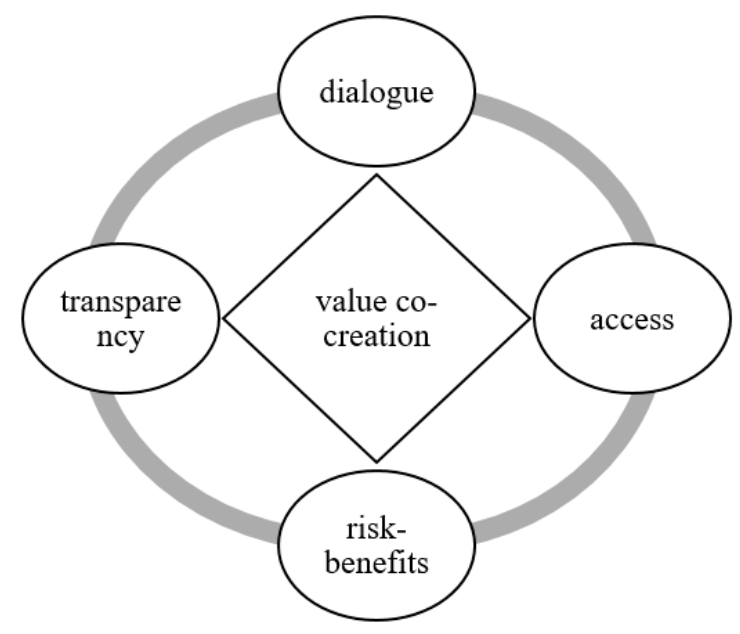

Figure 2. Dialogue, access, risk assessment, and transparency (DART) model. Source: [9] (p. 9).

A firm must provide customers with Access to information channels and tools for value co-creation [66]. Sharing challenges the notion that value can be co-created only through the ownership of resources. It can create new opportunities as it allows for participation without many resources (e.g., the access to on-demand printing) and the use of products without the responsibilities of ownership (e.g., car sharing). This, in turn, is closely connected to Transparency. Traditionally, companies have benefited from information asymmetry between the firm and its customers. This is changing, and nowadays information about products, processes, and technologies is becoming accessible, thus creating the transparency that fosters trust and cooperation. Both access and transparency are necessary for dialogue to take place.

Finally, the combination of dialogue, access, and transparency can lead to a clear assessment of Risks and benefits and allows the customer to make more informed and therefore better decisions. Conventionally, companies assume that they are better equipped to assess and manage risk than their customers. Therefore, when communicating with the customers, they tend to focus solely on the benefits and ignore the risks. However, with the move towards co-creation, the customers become active participants, and thanks to dialogue, access, and transparency, they can now evaluate the risks involved.

Several attempts have been made to test the DART model empirically. Albinsson, Perera, and Sauter operationalized the building blocks of the model (i.e., dialogue, access, transparency, risk-benefits) and proved that shared responsibility by the participants is positively connected to their perceptions of its components [66]. Also, high scores for the assessment of each component positively correlated with customer loyalty towards the company. In turn, Mazur and Zaborek offered criticism of the model's structure and usefulness [67]. They suggest that the components are not clearly defined and that there is too much overlap between them. They suggest that the structure of the model should be re-designed in search of new components that would allow for better discriminant validity for the model. Despite this criticism, the DART model remains a useful theoretical and managerial tool emphasizing key elements of the value co-creation process [56,68]. Our aim is the empirical verification of the DART model and of its main pillar, Dialogue, in explaining information sharing among the users of car sharing. 


\section{Data and Research Method}

While generally, car sharing is a mature technological and social innovation, in Poland it is just a three-year-old phenomenon, still with a relatively high momentum for growth. At the same time, due to the low level of social trust three decades ago when the transformation of the Polish economy and society started, it would be intriguing to understand the interrelation between Polish social capital and shared mobility.

The aim of our research was to explore the impact of social capital on information sharing in the course of value co-creation among car sharing users in Warsaw. We wanted to know which type of social trust (particular or general) might be more important in this process. Based on this, we formulated two research hypotheses (see Figure 3).

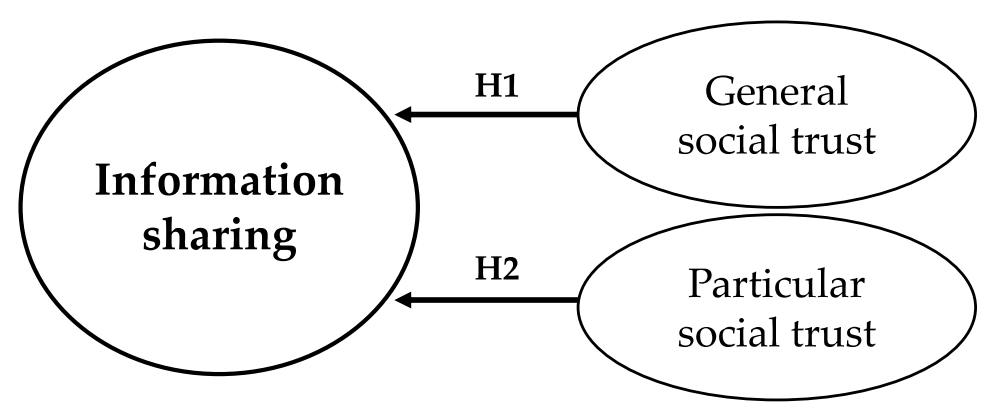

Figure 3. Research framework.

Hypothesis 1 (H1): Particular social trust is crucial in developing a dialogue with the car sharing operator and other service users.

Hypothesis 2 (H2): General social trust, which extends to people as a whole, has no effect on the willingness of customers to share information.

In June 2019, in cooperation with PANEK CS company, we conducted a survey that was carried out among car sharing customers of the PANEK operator (the biggest in Warsaw and one of the leaders in Poland).

The data used in this paper thus came from a web page survey of 1000 users of car sharing services provided by the PANEK CS company in Warsaw. At the time when the survey was conducted, the total number of car-sharing users registered by PANEK CS was close to 90,000 individuals. Around 25,000 of the PANEK CS users were active on the public Facebook fan page, and the survey was directed to them. The participants in the survey received a voucher for services at PANEK worth PLN 20 (around 4.5 euros), which did not seem enough to bias the recruitment of respondents.

The PANEK CS company was the first car sharing system in Warsaw and Poland, and it started to operate in spring 2017. It operated in the free-float mode for about two years, but at the beginning of 2019, it also implemented a mixed mode: Free-float and station-based (a few pilot projects at shopping centers and local business centers). PANEK CS is very active in terms of customer involvement in dialogue and interaction (Access from the DART model). It offers different channels for lively communication such as a webpage (panekcs.pl; ipanek.pl), a phone info line, Facebook, Instagram, Twitter, and Linkedin. The company follows users' opinions and suggestion obtained from communicators' comments in the application and also conducts short ad hoc surveys. Customers have the opportunity to communicate with the company and with each other through the social media. In comparison to other car sharing companies operating in Warsaw, PANEK CS seems to pay much more attention to the exploitation of the potential related to information sharing and value co-creation.

Thanks to the PANEK CS company, we were able to compare our sample characteristics with the characteristics of the whole population of car sharing users in Warsaw. We confirmed very close 
similarities between these two groups in terms of sex, age, education, length of use, year of obtaining a driving license, and a number of other features. For this reason, we can assume that our sample may be considered representative of the population of car sharing users in Warsaw in terms of major socio-economic characteristics. In 2019, PANEK CS was the biggest car sharing company in Warsaw, with around $45 \%$ of the market share (around 1100 cars).

The car sharing users in our sample, as in the wider population of PANEK CS users, were young people around 28 years old, mainly men, mostly living alone, who have completed secondary or tertiary education or are continuing with their education. They fit the general characteristics of other car sharing users in Poland (Table 2).

Table 2. Basic statistics regarding the respondents' sample.

\begin{tabular}{|c|c|c|c|c|c|}
\hline Age Group & $17-24$ & $25-29$ & $30-34$ & $35-39$ & 40 and Above \\
\hline Percent & 42.6 & 21.1 & 18.9 & 10.2 & 7.2 \\
\hline Education & Primary & Secondary & Tertiary & $\begin{array}{c}\text { Technical } \\
\text { Tertiary }\end{array}$ & $\begin{array}{c}\text { Continuing } \\
\text { learning }\end{array}$ \\
\hline$\%$ share & 2 & 29 & 31 & 13 & 25 \\
\hline Employment status & $\begin{array}{l}\text { Full-time } \\
\text { employed }\end{array}$ & Part time & Entrepreneur & Non-working & Other \\
\hline$\%$ share & 55 & 17 & 13 & 11 & 4 \\
\hline Monthly budget at disposal & 800 & 1800 & 3000 & 4500 & 7000 \\
\hline $\begin{array}{c}\text { Percentiles } \\
\text { Mean } \\
\text { Std. deviation }\end{array}$ & $10 \%$ & $25 \%$ & $\begin{array}{l}50 \% \\
3604.81 \\
4489.69\end{array}$ & $75 \%$ & $90 \%$ \\
\hline
\end{tabular}

In order to assess the determinants of the willingness of respondents to engage in a dialogue with the operator of car sharing, the response to the following question was used as the first dependent variable: 'Do you voluntarily share information with the operator of car sharing (e.g., about inappropriate use of the service by other users, ways to improve the service, etc.)?'

Exchange of information between the users of car sharing can also improve the functioning of the system because it helps to create and maintain a loyal consumer community. The consumers' intensity of networking was measured by their response to the following question: 'Do you exchange knowledge and opinions about the service with other users?' This was our second dependent variable, intended to capture the dialogue component of the DART model.

The third dependent variable gauged the engagement of respondents in the dialogue in the role of recipients of information. The response to the following question was used as the third dependent variable: 'Do you use the information about car sharing conveyed by other service users?'

All these questions had a numeric response that fell within the range from 1 (definitely disagree) to 5 (definitely agree). The set of control variables included the sex of the respondent and his or her income. Contextual demographic and economic variables have been shown to affect pro-environmental behavior through personal variables such as attitudes, beliefs, and norms [69].

We also controlled for expenditure on car sharing services, the degree of substitution or complementarity between traditional means of transport and car sharing, and pro-environmental consumption behavior.

Pro-environmental attitude was measured by using respondents' agreement (coded on a scale ranging from 1 to 5) with the following statement: 'It is important for me to use eco-friendly products'. In order to capture the potential of car sharing in replacing traditional means of transport, we used responses to this statement to indicate, on a scale from 0 to 10 , the extent to which a shared car substitutes for an owned car.

The set of control variables contained two proxies for the respondent's willingness to participate in information sharing and vcc. The variable support for dialogue was obtained from the respondents' agreement (coded on a scale ranging from 1 to 5) with the following statement: 'Do you support 
information sharing, including information on shared mobility?' The second variable, labelled satisfaction from dialogue, was obtained from the respondents' agreement (coded on a scale ranging from 1 to 5) with the following statement: 'I am satisfied when my activity contributes to improving the quality of sharing systems'. Finally, to account for the risk considerations, which are an important ingredient of the DART model, we included in the set of predictors the respondents' agreement (coded on a scale ranging from 1 to 5) with the following statement: 'I am afraid that information that I reveal could be used improperly'. This variable was labelled risk.

Particular trust was measured with the aid of the respondents' agreement (coded on a scale ranging from 1 to 5) with the following three statements: 'I have high trust in users of PANEKservices', 'I have high trust in users of car sharing', and 'I have high trust in members of my community (workplace, school, sports club, etc.)'. In the set of independent variables, we also included a measure of narrow particular trust that is confined to close family members. We conjecture that this type of trust is exclusive and does not promote exchange of information in a sharing system.

General trust was quantified by means of the respondents' agreement (coded on a scale ranging from 1 to 5) with the following two statements: 'I have high trust in acquaintances', and 'I have high trust in non-governmental organizations'.

The measures of particular trust turned out to be correlated, but no correlation was found between them and the measures of general trust as shown in Table 3.

Table 3. Correlation coefficients between measures of trust.

\begin{tabular}{|c|c|c|c|c|c|}
\hline & $\begin{array}{l}\text { Trust in Users of } \\
\text { PANEK Services }\end{array}$ & $\begin{array}{l}\text { Trust in Users } \\
\text { of Car Sharing }\end{array}$ & $\begin{array}{l}\text { Trust in Members of } \\
\text { My Community }\end{array}$ & $\begin{array}{l}\text { Trust in Family } \\
\text { Members }\end{array}$ & $\begin{array}{c}\text { Trust in } \\
\text { Acquaintances }\end{array}$ \\
\hline Trust in users of PANEK services & - & & & & \\
\hline Trust in users of car sharing & 0.8831 & - & & & \\
\hline $\begin{array}{l}\text { Trust in members of my } \\
\text { community }\end{array}$ & 0.5292 & 0.5416 & - & & \\
\hline Trust in family members & 0.1423 & 0.1302 & 0.3075 & - & \\
\hline Trust in acquaintances & 0.1755 & 0.1655 & 0.2146 & 0.0831 & - \\
\hline Trust in NGOs & 0.2344 & 0.2366 & 0.2778 & 0.1157 & 0.4070 \\
\hline
\end{tabular}

Due to the fact that the proxies for particular trust were correlated, we used the principal component analysis to construct an index of particular trust. The first principal component, labelled particular trust, explained $70 \%$ of the total variance of the individual variance of the three measures of particular trust (i.e., trust in users of PANEK services, in car sharing in general, and in members of the community). Since the variables used to measure general trust and narrow particular trust (i.e., trust in family members) were not highly correlated, they were used together in each model specification.

Although the regressands were 5-level variables, we estimated the models by robust OLS because respondents indicated agreement on a scale so there was no reason to reject the assumption that the differences between points on the scale are unequal. To eliminate gross outliers, we performed OLS regressions, and initial screening was based on Cook's distance, i.e., observations characterized by Cook's $D$ larger than 1 were eliminated. Thereafter, the procedure was iterative, i.e., weights were calculated from absolute residuals and the model was fit by OLS using those weights. Iterations stopped when the maximum change in weights decreased below the tolerance level $\left(10^{-6}\right)$. To ensure the robustness of the results, the parameters were also estimated by ordered logistic method.

\section{Empirical Results}

The estimation results are presented in Table 4. The dependent variable is the extent to which respondents voluntarily share information with the operator (column 1), share information with other users (column 2), or benefit from information conveyed by other users (column 3). Particular trust was measured in all model specifications by the index particular trust described in the previous section. 
Table 4. Determinants of information sharing with the service provider and other users; robust regression.

\begin{tabular}{|c|c|c|c|}
\hline Predictor Variables & (1) & (2) & (3) \\
\hline Sex/men & $\begin{array}{l}-0.122 \\
(0.092)\end{array}$ & $\begin{array}{l}-0.122 \\
(0.082)\end{array}$ & $\begin{array}{l}-0.092 \\
(0.084)\end{array}$ \\
\hline Income & $\begin{array}{c}0.000011 \\
(0.000010)\end{array}$ & $\begin{array}{l}-0.000008 \\
(0.000009)\end{array}$ & $\begin{array}{l}-0.000007 \\
(0.000009)\end{array}$ \\
\hline Expenditure on CS & $\begin{array}{l}0.000306^{*} \\
(0.000165)\end{array}$ & $\begin{array}{l}-0.000073 \\
(0.000146)\end{array}$ & $\begin{array}{c}0.000016 \\
(0.000149)\end{array}$ \\
\hline CS substitutes for private ownership & $\begin{array}{l}0.032 * * \\
(0.014)\end{array}$ & $\begin{array}{c}0.042^{* * *} \\
(0.012)\end{array}$ & $\begin{array}{c}0.038^{* * *} \\
(0.012)\end{array}$ \\
\hline Usage of environment friendly products & $\begin{array}{l}0.059^{* *} \\
(0.030)\end{array}$ & $\begin{array}{c}0.013 \\
(0.027)\end{array}$ & $\begin{array}{c}0.028 \\
(0.027)\end{array}$ \\
\hline Particular trust & $\begin{array}{l}0.053 \text { ** } \\
(0.025)\end{array}$ & $\begin{array}{c}0.069^{* * *} \\
(0.022)\end{array}$ & $\begin{array}{l}0.053^{* *} \\
(0.023)\end{array}$ \\
\hline Trust in close family members & $\begin{array}{l}-0.017 \\
(0.036)\end{array}$ & $\begin{array}{l}-0.003 \\
(0.032)\end{array}$ & $\begin{array}{l}-0.035 \\
(0.032)\end{array}$ \\
\hline Trust in NGOs & $\begin{array}{c}0.030 \\
(0.035)\end{array}$ & $\begin{array}{l}-0.021 \\
(0.031)\end{array}$ & $\begin{array}{l}0.006 \\
(0.031)\end{array}$ \\
\hline Trust in acquaintances & $\begin{array}{c}-0.077^{*} \\
(0.039)\end{array}$ & $\begin{array}{l}-0.003 \\
(0.035)\end{array}$ & $\begin{array}{c}0.000 \\
(0.036)\end{array}$ \\
\hline Support for dialogue & $\begin{array}{c}0.210^{* * *} \\
(0.042)\end{array}$ & $\begin{array}{c}0.315^{* * *} \\
(0.037)\end{array}$ & $\begin{array}{c}0.274^{* * *} \\
(0.038)\end{array}$ \\
\hline Satisfaction from dialogue & $\begin{array}{l}0.091 * * \\
(0.041)\end{array}$ & $\begin{array}{l}0.077^{* *} \\
(0.036)\end{array}$ & $\begin{array}{c}0.160 * * * \\
(0.037)\end{array}$ \\
\hline Risk & $\begin{array}{l}-0.031 \\
(0.030)\end{array}$ & $\begin{array}{l}-0.028 \\
(0.027)\end{array}$ & $\begin{array}{c}0.019 \\
(0.028)\end{array}$ \\
\hline Constant & $\begin{array}{l}-0.122 \\
(0.092)\end{array}$ & $\begin{array}{l}-0.122 \\
(0.082)\end{array}$ & $\begin{array}{l}-0.092 \\
(0.084)\end{array}$ \\
\hline $\begin{array}{l}\text { Observations } \\
\text { R squared }\end{array}$ & $\begin{array}{c}978 \\
0.119\end{array}$ & $\begin{array}{c}978 \\
0.202\end{array}$ & $\begin{array}{c}978 \\
0.212\end{array}$ \\
\hline
\end{tabular}

Notes: Standard errors are shown in brackets; asterisks indicate the significance level: ${ }^{* * *} p<0.01,{ }^{* *} p<0.05$, $* p<0.1$. CS stands for car sharing.

The results in Table 4 reveal that sex, income, and expenditure on car sharing services did not significantly affect the willingness to share information with the service operator and other service users.

In relation to the first hypothesis (H1), there are convincing reasons to believe that particular trust increases the flow of information from consumers to car sharing operators because all estimated coefficients of the index of particular trust are positive and statistically significant. It seems that general trust $(\mathrm{H} 2)$ had no effect on information sharing because higher trust in NGOs and acquaintances were not statistically significant.

It has to be noted that trust in close family members did not enhance information sharing. While Polish people and respondents in our sample generally value family relations very highly (trust in close family relatives), it usually has an exclusive character and might not contribute to sharing (even if family trust is seen as close to particular trust).

Individuals who are inclined to engage in dialogue with the supplier of services and who feel satisfaction when contributing to vcc through dialogue are more likely to share information with the service operator and other users. Fears of Risk (element of DART model) from abuse of information by the service operator were not statistically significant. This implies that particular trust is a significant determinant of the vcc, even when the important control variables suggested by the DART approach are included in the model.

Apart from the positive verification of our hypotheses, we also identified some interesting topics for further research. We observed that respondents who consider car sharing to be a substitute for private ownership contributed to value co-creation by sharing information. We also noticed that 
consumers who were more environmentally aware revealed a higher propensity to be involved in a dialogue with the operator but not with the other users.

The outcome variable was ordered, and respondents should not perceive differences between adjacent points on the scale as equidistant. Therefore, to ensure the robustness of results, we estimated the models by ordered logistic regression with robust standard errors. The estimated odds ratios are shown in Table 5.

Table 5. Determinants of information sharing with the service provider and other users; ordered logit estimates.

\begin{tabular}{cccc}
\hline Predictor Variables & $\mathbf{( 1 )}$ & $\mathbf{( 2 )}$ & $\mathbf{( 3 )}$ \\
\hline Sex/men & -0.229 & $-0.342^{* *}$ & -0.255 \\
Income & $(0.173)$ & $(0.168)$ & $(0.167)$ \\
& 0.000017 & -0.000015 & -0.000013 \\
Expenditure on CS & $(0.000015)$ & $(0.000017)$ & $(0.000015)$ \\
& $0.000625^{* * *}$ & -0.000048 & 0.000054 \\
CS substitutes for private ownership & $(0.000240)$ & $(0.000330)$ & $(0.000295)$ \\
Usage of environment friendly products & $0.054^{* *}$ & $0.078^{* * *}$ & $0.064^{* *}$ \\
& $(0.024)$ & $(0.025)$ & $(0.025)$ \\
Particular trust & $0.104^{*}$ & 0.008 & 0.055 \\
& $(0.059)$ & $(0.059)$ & $(0.059)$ \\
Trust in close family members & $0.109^{* * *}$ & $0.178 * * *$ & $0.142 * * *$ \\
Trust in NGOs & $(0.048)$ & $(0.046)$ & $(0.049)$ \\
& -0.025 & -0.010 & -0.086 \\
Trust in acquaintances & $(0.076)$ & $(0.071)$ & $(0.073)$ \\
Support for dialogue & 0.047 & -0.060 & 0.009 \\
& $(0.061)$ & $(0.065)$ & $(0.066)$ \\
Satisfaction from dialogue & $-0.134^{*}$ & 0.018 & -0.005 \\
Rseudo-R squared & $(0.072)$ & $(0.066)$ & $(0.070)$ \\
Risk & $0.362^{* * *}$ & $0.575 * * *$ & $0.490 * * *$ \\
& $(0.082)$ & $(0.090)$ & $(0.094)$ \\
& $0.161^{* * *}$ & 0.110 & $0.244^{* * *}$ \\
& $(0.078)$ & $(0.082)$ & $(0.082)$ \\
& -0.070 & -0.082 & 0.021 \\
& $(0.063)$ & $(0.058)$ & $(0.063)$ \\
\hline & 978 & 978 & 978 \\
& 0.042 & 0.068 & 0.068 \\
\hline
\end{tabular}

Notes: Odds ratios are reported in the table. Robust standard errors are shown in brackets; asterisks indicate the significance level: ${ }^{* * *} p<0.01,{ }^{* *} p<0.05, * p<0.1$. CS stands for car sharing.

The results obtained from the ordered logistic regression analysis confirm earlier findings of an unambiguously positive association between particular trust (not confined to close family members) and the propensity to share information with the operator of car sharing. General trust is not a significant determinant of value creation through dialogue.

Although the correlation coefficients between the measures of particular and general trust were low (see Table 3), we decided to test the significance of the latter when the former were excluded from the set of independent variables. This would help to decide whether or not the hypothesis $\mathrm{H} 2$ holds if the impact of particular trust is not controlled for. The set of predictors was extended to include blood donation as an indirect measure of general trust, following Kuroki, Guiso et al., and Buonanno et al. [70-72]. Estimation results are presented in Table 6. The dependent variable is the extent to which respondents voluntarily share information with the operator (column 1), share information with the other users (column 2), or benefit from information conveyed by other users (column 3). 
Table 6. Determinants (other than particular trust) of information sharing with the service provider and other users; ordered logit estimates.

\begin{tabular}{cccc}
\hline Predictor Variables & $\mathbf{( 1 )}$ & $\mathbf{( 2 )}$ & $\mathbf{( 3 )}$ \\
\hline Sex/men & -0.231 & $-0.301^{*}$ & -0.243 \\
Income & $(0.175)$ & $(0.166)$ & $(0.167)$ \\
Expenditure on CS & 0.000013 & -0.000020 & -0.000017 \\
& $(0.000014)$ & $(0.000017)$ & $(0.000015)$ \\
CS substitutes for private ownership & $0.000626^{* *}$ & -0.000047 & 0.000061 \\
& $(0.000252)$ & $(0.000347)$ & $(0.000314)$ \\
Usage of environment friendly products & $0.061^{* * *}$ & $0.088^{* * *}$ & $0.072 * * *$ \\
& $(0.024)$ & $(0.024)$ & $(0.025)$ \\
Trust in close family members & $0.110^{*}$ & 0.015 & 0.060 \\
& $(0.059)$ & $(0.059)$ & $(0.058)$ \\
Trust in NGOs & -0.022 & -0.003 & -0.086 \\
Trust in acquaintances & $(0.073)$ & $(0.069)$ & $(0.071)$ \\
& 0.058 & -0.031 & 0.037 \\
Blood donation & $(0.060)$ & $(0.064)$ & $(0.064)$ \\
& -0.101 & 0.057 & 0.029 \\
Support for dialogue & $(0.069)$ & $(0.065)$ & $(0.066)$ \\
& -0.199 & -0.083 & -0.018 \\
Satisfaction from dialogue & $(0.151)$ & $(0.161)$ & $(0.165)$ \\
Risk & $0.389 * * *$ & $0.614 * * *$ & $0.518 * * *$ \\
& $(0.082)$ & $(0.087)$ & $(0.090)$ \\
Pseudo R squared & $0.171^{* * *}$ & $0.132 *$ & $0.262 * * *$ \\
& $(0.076)$ & $(0.080)$ & $(0.080)$ \\
& -0.033 & -0.032 & 0.061 \\
& $(0.059)$ & $(0.056)$ & $(0.060)$ \\
\hline Observations & 988 & 988 & 988 \\
& 0.041 & 0.063 & 0.065 \\
\hline
\end{tabular}

Notes: Robust standard errors are shown in brackets; asterisks indicate the significance level: ${ }^{* * *} p<0.01,{ }^{* *} p<0.05$, ${ }^{*} p<0.1$. CS stands for car sharing.

The results shown in Table 6 reveal that general trust is not a determinant of the dialogue with the operator of car sharing even if we do not control for particular trust, while the latter remains a significant determinant of the dialogue if the impact of general trust is controlled for.

In order to strengthen the conclusion that particular trust is of greater importance for dialogue and value co-creation than general trust, we analyzed the determinants of the support of car sharing users in Poland for mandatory information sharing. The first question that we used to construct the dependent variable concerns PANEK clients: 'Do you agree that information, knowledge, experience sharing should be an obligation of PANEK users?' The two remaining opinions used to construct the response variables were more general and go beyond car sharing. The respondents assessed (on a scale from 1 to 5) the extent to which they agreed with the statements that 'Consumers have an obligation to provide feedback to the supplier on the service they use' and 'Consumers have an obligation to share information and help other service users'. The set of predictors was not changed and includes the index of particular trust. Estimation results are presented in Table 7 in column (1) for the model on mandatory information sharing with PANEK users, in column (2) for the model on mandatory information sharing with the service providers in general, and in column (3) for the model on information sharing with other service users. 
Table 7. Determinants of support for obligatory information sharing with the service providers and other users; robust regression.

\begin{tabular}{|c|c|c|c|}
\hline Predictor Variables & (1) & (2) & (3) \\
\hline \multirow[t]{2}{*}{ Sex/men } & -0.079 & -0.110 & -0.010 \\
\hline & $(0.096)$ & $(0.073)$ & $(0.080)$ \\
\hline \multirow[t]{2}{*}{ Income } & -0.000009 & 0.000002 & 0.000003 \\
\hline & $(0.000011)$ & $(0.000008)$ & $(0.000009)$ \\
\hline \multirow[t]{2}{*}{ Expenditure on CS } & 0.000137 & 0.000161 & -0.000002 \\
\hline & $(0.000172)$ & $(0.000131)$ & $(0.000144)$ \\
\hline \multirow[t]{2}{*}{ CS substitutes for private ownership } & $0.058^{* * *}$ & $0.024^{* *}$ & $0.024^{* *}$ \\
\hline & $(0.014)$ & $(0.011)$ & $(0.012)$ \\
\hline \multirow{2}{*}{ Usage of environment friendly products } & -0.028 & $0.073^{* * *}$ & $0.043 *$ \\
\hline & $(0.031)$ & $(0.024)$ & $(0.026)$ \\
\hline \multirow[t]{2}{*}{ Particular trust } & $0.106^{* * *}$ & $0.084^{* * *}$ & $0.181^{* * *}$ \\
\hline & $(0.026)$ & $(0.020)$ & $(0.022)$ \\
\hline \multirow{2}{*}{ Trust in close family members } & $-0.065^{*}$ & 0.046 & -0.005 \\
\hline & $(0.037)$ & $(0.028)$ & $(0.031)$ \\
\hline \multirow[t]{2}{*}{ Trust in NGOs } & 0.036 & -0.007 & -0.043 \\
\hline & $(0.036)$ & $(0.027)$ & $(0.030)$ \\
\hline \multirow[t]{2}{*}{ Trust in acquaintances } & -0.023 & -0.033 & 0.041 \\
\hline & $(0.041)$ & $(0.031)$ & $(0.034)$ \\
\hline \multirow[t]{2}{*}{ Support for dialogue } & $0.337^{* * *}$ & $0.581^{* * *}$ & $0.662 * * *$ \\
\hline & $(0.043)$ & $(0.033)$ & $(0.036)$ \\
\hline \multirow[t]{2}{*}{ Satisfaction from dialogue } & -0.052 & $0.135^{* * *}$ & $-0.062 *$ \\
\hline & $(0.042)$ & $(0.032)$ & $(0.035)$ \\
\hline \multirow[t]{2}{*}{ Risk } & 0.032 & 0.039 & $0.051 *$ \\
\hline & $(0.032)$ & $(0.024)$ & $(0.027)$ \\
\hline \multirow[t]{2}{*}{ Constant } & $2.600 * * *$ & 0.300 & $0.637^{* * *}$ \\
\hline & $(0.254)$ & $(0.193)$ & $(0.212)$ \\
\hline Observations & 978 & 974 & 974 \\
\hline R squared & 0.143 & 0.509 & 0.461 \\
\hline
\end{tabular}

Notes: Standard errors are shown in brackets; asterisks indicate the significance level: ${ }^{* * *} p<0.01,{ }^{* *} p<0.05$, ${ }^{*} p<0.1$. CS stands for car sharing.

The result presented in Table 7 confirm the previous findings. The support for obligatory information sharing with the service operator and other service users was not affected by the sex of the respondent, expenditure on car sharing services, or income. An increase in the perceived degree of substitutability between car sharing and car ownership fosters an inclination to accept mandatory information sharing. More importantly, general trust did not seem to be a determinant of the support for mandatory information sharing between customers and between service users and service provider. In contrast, particular trust, with the exception of trust in close family members, remained a significant factor that enhanced the exchange of information. This major conclusion is supported by the results of ordered logistic estimates, presented in Table 8.

Table 8. Determinants of support for obligatory information sharing with the service providers and other users; ordered logit estimates.

\begin{tabular}{cccc}
\hline Predictor Variables & $\mathbf{( 1 )}$ & $\mathbf{( 2 )}$ & $\mathbf{( 3 )}$ \\
\hline Sex/men & -0.203 & $-0.332 * *$ & -0.114 \\
& $(0.161)$ & $(0.156)$ & $(0.158)$ \\
Income & -0.000013 & 0.000005 & 0.000006 \\
& $(0.000019)$ & $(0.000017)$ & $(0.000013)$ \\
Expenditure on CS & 0.000221 & 0.000246 & -0.000136 \\
& $(0.000205)$ & $(0.000218)$ & $(0.000208)$ \\
\hline
\end{tabular}


Table 8. Cont.

\begin{tabular}{cccc}
\hline Predictor Variables & $\mathbf{( 1 )}$ & $\mathbf{( 2 )}$ & $\mathbf{( 3 )}$ \\
\hline CS substitutes for private ownership & $0.096^{* * *}$ & $0.050^{*}$ & $0.050^{*}$ \\
Usage of environment friendly products & $(0.025)$ & $(0.026)$ & $(0.026)$ \\
& -0.048 & $0.156^{* * *}$ & 0.086 \\
Particular trust & $(0.054)$ & $(0.060)$ & $(0.060)$ \\
& $0.185^{* * *}$ & $0.203^{* * *}$ & $0.392^{* * *}$ \\
Trust in close family members & $(0.044)$ & $(0.049)$ & $(0.052)$ \\
Trust in NGOs & $-0.114^{*}$ & 0.097 & 0.008 \\
& $(0.064)$ & $(0.064)$ & $(0.064)$ \\
Trust in acquaintances & 0.064 & 0.001 & -0.059 \\
& $(0.061)$ & $(0.070)$ & $(0.068)$ \\
Support for dialogue & -0.049 & -0.069 & 0.080 \\
& $(0.068)$ & $(0.079)$ & $(0.075)$ \\
Satisfaction from dialogue & $0.529 * * *$ & $1.157 * * *$ & $1.152^{* * *}$ \\
Risk & $(0.087)$ & $(0.112)$ & $(0.101)$ \\
& -0.084 & $0.257 * * *$ & -0.123 \\
Observations & $(0.073)$ & $(0.083)$ & $(0.077)$ \\
Pseudo-R squared & 0.075 & 0.090 & $0.135 * *$ \\
\hline
\end{tabular}

Notes: Odds ratios are reported in the table. Robust standard errors are shown in brackets; asterisks indicate the significance level: ${ }^{* * *} p<0.01,{ }^{* *} p<0.05,{ }^{*} p<0.1$. CS stands for car sharing.

\section{Conclusions and Further Research}

Car sharing is an alternative to car ownership and can result in environmental benefits, including reduction of congestion and smog problems, but its prerequisite is relatively high replacement rate for private cars. Despite the individual and social benefits, the car sharing market faces many challenges. We explored one important channel that could improve the functioning of a shared mobility system, namely information sharing as part of the value co-creation process. Our results contribute to the empirical investigation of the DART model, which is recognized as one of the most suitable concepts for exploring vcc. While we concentrated on the Dialogue component in our research, we also referred to other dimensions of the DART model.

This paper is unique in its attempt to assess the impact of trust on the intensity of dialogue within a community of consumers and with the provider of a car sharing service. More social involvement by the customer would increase the efficiency of the whole system and make it more interactive and adaptable. Using novel data from a survey of the clients of a car sharing company in Warsaw, we showed that general and particular social trust have distinctive impacts on the willingness to share information. The former has no effect on information sharing, whereas the latter intensifies communication. Therefore, particular social trust is not only a necessary (but not sufficient) cause of general social trust but also an important component of the development of sustainable transport systems.

We can also conclude that PANEK CS customers seem to constitute a coherent group of people who trust each other, and this determines their involvement in a dialogue with the operator and other users. It is a positive sign, indicating some level of social trust embodied in the population of young Polish people, which has the potential to result in a higher level of general social trust. It also gives room for further sharing economy and shared mobility market developments as the young generation is generally more open to the adoption of social and technological innovation. Our results can also be a sign of intergenerational change in the level of social trust and a mark of a catch-up by Polish (young) people with more trustful societies.

What is also worth highlighting is that those car sharing users who are more inclined in dialogue with the operator are also those who are more likely to use eco-friendly products and to consider car 
sharing as substitutive for private ownership. This means that their approach to mobility is probably more environmentally oriented and more in line with sustainable development goals. We also observed that for respondents who are in favor of conducting dialogue (support it) and benefit from information sharing (observed as an increased quality of services) particular trust might be more important because it is more mercantilist in nature and has its own motivators. The confirmation of our hypothesis, which requires further research, might have its roots in social exchange theory, which states that information sharing can be treated as a good and exchanged for something, not for altruistic reasons but because of self-interest [73]. In our situation, those consumers who see a shared vehicle as a close substitute for the private car, who see positive results from information sharing, and who see positive results from taking part in dialogue have their stake in the game and engage more in sharing.

We are conscious that the results of our research cannot be generalized to the whole population of car sharing users in Poland; the study has its own limitations as well as some implications for further research.

The development of the car sharing market depends on many factors and we examined only one of them, namely the propensity of car sharing users to co-create value through information sharing with the company and other customers. Our research indicates that the value co-creation process might be a result of particular trust and not a general one, which is in line with the literature indicating that East Europeans base their relations on a relatively small circle of people [47]. However, it would be interesting to more clearly understand the interrelation between those two dimensions of social trust in a transitioning economy such as Poland and to know what its implications are for the sharing economy of the future. Moreover, it would be interesting to conduct a deeper investigation into the other building blocks of the DART model as well as into alternative models, such as that introduced by Yi and Gong in 2013 [74].

Second, value co-creation demands a more active role of sharing operators and cities. While the shared mobility and car sharing literature is mostly concentrated on users, there is a growing need to recognize the challenges faced by the shared mobility operators and cities authorities' in creating mobility ecosystem complementary to public transport.

Collective interests are of the greatest importance when addressing mobility issues, and that is why, in order to involve the customers in value co-creation processes, sufficient effort must be put into developing rules, incentives, and trust by the sharing operators and the local authorities. Shared mobility and value co-creation demands a more active role by the sharing platform operators who have to realize the value of data and relations management and how these can increase their competitive advantage [5]. Sharing operators' intangible assets and IT smart cities solutions are enablers for the development of a unique selling proposition that includes incentives for value co-creation by customers and more optimal functioning of the local mobility system. IT capacities will make the theories of co-creation pioneers Prahalad and Ramaswamy more relevant than they are now $[9,65]$.

Third, from the management point of view, sharing may be profitable for building an information collection and knowledge base as well as a competitive advantage for the sharing operator [75]. Moreover, the social component of a sharing economy shifts the consumers' attention from ownership to utilization, while the sharing economy is also more interrelated with social capital and social trust than with traditional centralized markets $[5,7,8]$. The effectiveness of dialogue in the DART model will largely depend on the choice of communication methods, which will depend on the clients' profile. That is why it is so important to assess the conditions impacting the dialogue on co-creating value, especially from the perspective of new customers who will bring similar or even deepened characteristics to the market in the near future.

Author Contributions: All of the authors contributed significantly to the completion of this manuscript, conceiving and designing the research, writing and improving the paper. All authors have read and approved the manuscript.

Funding: This research received no external funding and the APC was funded by Faculty of Management University of Warsaw.

Conflicts of Interest: The authors declare no conflict of interest. 


\section{References}

1. Jerrett, M.; Burnett, R.T.; Beckerman, B.S.; Turner, M.C.; Krewski, D.; Thurston, G.; Martin, R.V.; van Donkelaar, A.; Hughes, E.; Shi, Y.; et al. Spatial Analysis of Air Pollution and Mortality in California. Am. J. Respir. Crit. Care Med. 2013, 188, 593-599. [CrossRef] [PubMed]

2. Wu, X.; Zhi, Q. Impact of Shared Economy on Urban Sustainability: From the Perspective of Social, Economic, and Environmental Sustainability. Energy Procedia 2016, 104, 191-196. [CrossRef]

3. Bates, J.; Leibling, D. Spaced out, Perspectives on Parking Policy; Rac Foundations: London, UK, 2012.

4. Katzev, R. Car Sharing: A New Approach to Urban Transportation Problems. Anal. Soc. Issues Public Policy 2003, 3, 65-86. [CrossRef]

5. Kang, S.; Na, Y.K. The Effect of the Relationship Characteristics and Social Capital of the Sharing Economy Business on the Social Network, Relationship Competitive Advantage, and Continuance Commitment. Sustainability 2018, 10, 2203. [CrossRef]

6. Huurne, M.T.; Ronteltap, A.; Corten, R.; Buskens, V. Antecedents of trust in the sharing economy: A systematic review. J. Consum. Behav. 2017, 16, 485-498. [CrossRef]

7. Rifkin, J. The Zero Marginal Cost Society: The Internet of Things, the Collaborative Commons, and the Eclipse of Capitalism; Palgrave Macmillan: New York, NY, USA, 2014; ISBN 9781137278463.

8. Wang, Y.-B.; Ho, C.-W. No Money? No Problem! The Value of Sustainability: Social Capital Drives the Relationship among Customer Identification and Citizenship Behavior in Sharing Economy. Sustainability 2017, 9, 1400. [CrossRef]

9. Prahalad, C.K.; Ramaswamy, V. Co-creation experiences: The next practice in value creation. J. Interact. Mark. 2004, 18, 5-14. [CrossRef]

10. Prettenthaler, F.E.; Steininger, K.W. From ownership to service use lifestyle: The potential of car sharing. Ecol. Econ. 1999, 28, 443-453. [CrossRef]

11. Truffer, B. User-led Innovation Processes: The Development of Professional Car Sharing by Environmentally Concerned Citizens. Innov. Eur. J. Soc. Sci. Res. 2003, 16, 139-154. [CrossRef]

12. Uslaner, E.M. Trust as a moral value. In Handbook of Social Capital; Oxford University Press: Oxford, UK, 2008; pp. 101-121.

13. Lan, J.; Ma, Y.; Zhu, D.; Mangalagiu, D.; Thornton, T. Enabling Value Co-Creation in the Sharing Economy: The Case of Mobike. Sustainability 2017, 9, 1504. [CrossRef]

14. Heinrichs, H. Sharing Economy: A Potential New Pathway to Sustainability. GAIA-Ecol. Perspect. Sci. Soc. 2013, 22, 228-231. [CrossRef]

15. Wang, C.; Zhang, P. The Evolution of Social Commerce: The People, Management, Technology, and Information Dimensions. CAIS 2012, 31, 5. [CrossRef]

16. Hamari, J.; Sjöklint, M.; Ukkonen, A. The sharing economy: Why people participate in collaborative consumption. J. Assoc. Inf. Sci. Technol. 2016, 67, 2047-2059. [CrossRef]

17. Botsman, R.; Rogers, R. What's Mine Is Yours: The Rise of Collaborative Consumption, 1st ed.; Harper Business: New York, NY, USA, 2010; ISBN 9780061963544.

18. Wardak, P.; Zalega, T. Konsumpcja kolaboratywna jako nowy trend konsumencki. Studia i Mater. Wydziału Zarzadzania UW 2013, 2013, 33-42. [CrossRef]

19. Humphreys, A.; Grayson, K. The Intersecting Roles of Consumer and Producer: A Critical Perspective on Co-production, Co-creation and Prosumption. Sociol. Compass 2008, 2, 963-980. [CrossRef]

20. Ritzer, G.; Jurgenson, N. Production, Consumption, Prosumption: The nature of capitalism in the age of the digital 'prosumer'. J. Consum. Cult. 2010, 10, 13-36. [CrossRef]

21. Belk, R. You are what you can access: Sharing and collaborative consumption online. J. Bus. Res. 2014, 67, 1595-1600. [CrossRef]

22. Tchorek, G.; Allen, A.; Dziewanowska, K.; Geodecki, T.; Kozioł, W.; Kurtyka, M.; Skrzypek, J.; Targowski, F.; Wójtowicz, S. Electric Carsharing as an Interdisciplinary Test Ground of Various Fields of Study. Studia $i$ Mater. Wydziatu Zarzadzania UW. accepted for publication.

23. Shaheen, S.A.; Mallery, M.A.; Kingsley, K.J. Personal vehicle sharing services in North America. Res. Transp. Bus. Manag. 2012, 3, 71-81. [CrossRef]

24. Münzel, K.; Boon, W.; Frenken, K.; Vaskelainen, T. Carsharing business models in Germany: Characteristics, success and future prospects. Inf. Syst. E-Bus. Manag. 2018, 16, 271-291. [CrossRef] 
25. Nijland, H.; van Meerkerk, J. Mobility and environmental impacts of car sharing in the Netherlands. Environ. Innov. Soc. Transit. 2017, 23, 84-91. [CrossRef]

26. Becker, H.; Ciari, F.; Axhausen, K.W. Measuring the car ownership impact of free-floating car-sharing-A case study in Basel, Switzerland. Transp. Res. Part. D Transp. Environ. 2018, 65, 51-62. [CrossRef]

27. Williamson, O.E. The Economics of Organization: The Transaction Cost Approach. Am. J. Soc. 1981, 87, 548-577. [CrossRef]

28. William, D.N. Economic Growth and Climate: The Carbon Dioxide Problem. Am. Econ. Rev. Am. Econ. Assoc. 1977, 67, 341-346.

29. Putnam, R.D. Making Democracy Work: Civic Traditions in Modern Italy; Princeton University Press: Princeton, NJ, USA, 1993.

30. Kanwal, A.; Rajput, A. A Transaction Cost Framework in Supply Chain Relationships: A Social Capital Perspective. J. Relatsh. Mark. 2016, 15, 92-107. [CrossRef]

31. Vargo, S.L.; Akaka, M.A.; Vaughan, C.M. Conceptualizing Value: A Service-ecosystem View. J. Creat. Value 2017, 3, 117-124. [CrossRef]

32. Binkhorst, E.; Den Dekker, T. Agenda for Co-Creation Tourism Experience Research. J. Hosp. Mark. Manag. 2009, 18, 311-327. [CrossRef]

33. Prebensen, N.K.; Vittersø, J.; Dahl, T.I. Value co-creation significance of tourist resources. Ann. Tour. Res. 2013, 42, 240-261. [CrossRef]

34. Kamal, P.; Jim, Q.C. Trust in sharing economy. PACIS 2016 Proc. 2016, 10, 109. Available online: http: //aisel.aisnet.org/pacis2016/10 (accessed on 20 May 2020).

35. Hawlitschek, F.; Teubner, T.; Weinhardt, C. Trust in the Sharing Economy. Die Unternehm. 2016, 70, $26-44$. [CrossRef]

36. Hofmann, E.; Hartl, B.; Penz, E. Power versus trust-what matters more in collaborative consumption? J. Serv. Mark. 2017, 31, 589-603. [CrossRef]

37. Shao, Z.; Yin, H. Trust Building in the Car-Sharing Platform: An Empirical Study in China. CONF-IRM Proc. 2018, 47, 1-12.

38. Möhlmann, M. Collaborative consumption: Determinants of satisfaction and the likelihood of using a sharing economy option again. J. Consum. Behav. 2015, 14, 193-207. [CrossRef]

39. Kolankiewicz, G. Social capital and social change. Br. J. Sociol. 1996, 47, 427-441. [CrossRef]

40. Chloupkova, J.; Svendsen, G.L.H.; Svendsen, G.T. Building and destroying social capital: The case of cooperative movements in Denmark and Poland. Agric. Hum. Values 2003, 20, 241-252. [CrossRef]

41. Paldam, M. Social Capital: One or Many? Definition and Measurement. J. Econ. Surv. 2000, 14, $629-653$. [CrossRef]

42. Hjollund, L.; Paldam, M.; Svendsen, G.T. Social capital in Russia and Denmark: A comparative study. Aarhus Sch. Bus. Work. Pap. 2001, 01-13, 1-29.

43. Robbins, B.G. From the general to the specific: How social trust motivates relational trust. Soc. Sci. Res. 2016, 55, 16-30. [CrossRef]

44. Woolcock, M. Social Capital and Economic Development: Toward a Theoretical Synthesis and Policy Framework. Theory Soc. 1998, 27, 151-208. [CrossRef]

45. Sabatini, F. The Empirics of Social Capital and Economic Development: A Critical Perspective. SSRN J. 2006, 15, 1-34. [CrossRef]

46. Ferrari, M.Z. Beyond Uncertainties in the Sharing Economy: Opportunities for Social Capital. Eur. J. Risk Regul. 2016, 7, 664-674. [CrossRef]

47. Newton, K.; Zmerli, S. Three forms of trust and their association. Eur. Political Sci. Rev. 2011, 3, 169-200. [CrossRef]

48. Baier, A. Trust and Antitrust. Ethics 1986, 96, 231-260. [CrossRef]

49. Rotter, J.B. Generalized expectancies for interpersonal trust. Am. Psychol. 1971, 26, 443-452. [CrossRef]

50. Robbins, B.G. What is Trust? A Multidisciplinary Review, Critique, and Synthesis: What is Trust? Sociol. Compass 2016, 10, 972-986. [CrossRef]

51. Gummerus, J. Value creation processes and value outcomes in marketing theory: Strangers or siblings? Mark. Theory 2013, 13, 19-46. [CrossRef]

52. Smith, L.A.; Ng, I.C.L. Service Systems for Value Co-creation. WMG Serv. Syst. Res. Group Work. Pap. 2012, $01 / 12,1-19$. 
53. Hirschman, E.C.; Holbrook, M.B. Hedonic Consumption: Emerging Concepts, Methods and Propositions. J. Mark. 1982, 46, 92. [CrossRef]

54. Holbrook, M. Consumer Value: A Framework for Analysis and Research; Routledge: New York, NY, USA, 2002; ISBN 9780203010679.

55. Holbrook, M.B. Consumption experience, customer value, and subjective personal introspection: An illustrative photographic essay. J. Bus. Res. 2006, 59, 714-725. [CrossRef]

56. Zaborek, P.; Mazur, J. Exploring Links Between Engaging Customers in Value Co-Creation and Product Innovativeness. Int. J. Manag. Econ. 2017, 53, 82-106. [CrossRef]

57. Maglio, P.P.; Spohrer, J. Fundamentals of service science. J. Acad. Mark. Sci. 2008, 36, 18-20. [CrossRef]

58. Vargo, S.L.; Lusch, R.F. Service-dominant logic 2025. Int. J. Res. Mark. 2017, 34, 46-67. [CrossRef]

59. Vargo, S.L. Toward a transcending conceptualization of relationship: A service-dominant logic perspective. J. Bus. Ind. Mark. 2009, 24, 373-379. [CrossRef]

60. Lusch, R.F.; Vargo, S.L.; Wessels, G. Toward a conceptual foundation for service science: Contributions from service-dominant logic. IBM Syst. J. 2008, 47, 5-14. [CrossRef]

61. Payne, A.F.; Storbacka, K.; Frow, P. Managing the co-creation of value. J. Acad. Mark. Sci. 2008, 36, 83-96. [CrossRef]

62. Bharti, K.; Agrawal, R.; Sharma, V. Literature Review and Proposed Conceptual Framework. Int. J. Mark. Res. 2015, 57, 571-604. [CrossRef]

63. Leclercq, T.; Hammedi, W.; Poncin, I. Ten years of value cocreation: An integrative review. Rech. et Appl. en Mark. (English Edition) 2016, 31, 26-60. [CrossRef]

64. Prahalad, C.; Ramaswamy, V. Co-Opting Customer Competence. Harv. Bus. Rev. 2000, 78, 79-87.

65. Prahalad, C.K.; Ramaswamy, V. Co-creating unique value with customers. Strategy Leadersh. 2004, 32, 4-9. [CrossRef]

66. Albinsson, P.A.; Perera, B.Y.; Sautter, P.T. DART Scale Development: Diagnosing a Firm's Readiness for Strategic Value Co-creation. J. Mark. Theory Pract. 2016, 24, 42-58. [CrossRef]

67. Mazur, J.; Zaborek, P. Validating Dart Model. Int. J. Manag. Econ. 2014, 44, 106-125. [CrossRef]

68. Ramaswamy, V. Co-creating value through customers' experiences: The Nike case. Strategy Leadersh. 2008, 36, 9-14. [CrossRef]

69. Black, J.S.; Stern, P.C.; Elworth, J.T. Personal and contextual influences on househould energy adaptations. J. Appl. Psychol. 1985, 70, 3-21. [CrossRef]

70. Kuroki, M. Does social trust increase individual happiness in Japan? Jpn. Econ. Rev. 2011, 62, 444-459. [CrossRef]

71. Guiso, L.; Sapienza, P.; Zingales, L. The Role of Social Capital in Financial Development. Am. Econ. Rev. 2004, 94, 526-556. [CrossRef]

72. Buonanno, P.; Montolio, D.; Vanin, P. Does Social Capital Reduce Crime? J. Law Econ. 2009, 52, 145-170. [CrossRef]

73. Constant, D.; Kiesler, S.; Sproull, L. What's Mine Is Ours, or Is It? A Study of Attitudes about Information Sharing. Inf. Syst. Rese. 1994, 5, 400-421. [CrossRef]

74. Yi, Y.; Gong, T. Customer value co-creation behavior: Scale development and validation. J. Bus. Res. 2013, 66, 1279-1284. [CrossRef]

75. Yli-Renko, H.; Autio, E.; Tontti, V. Social capital, knowledge, and the international growth of technology-based new firms. Int. Bus. Rev. 2002, 11, 279-304. [CrossRef]

(C) 2020 by the authors. Licensee MDPI, Basel, Switzerland. This article is an open access article distributed under the terms and conditions of the Creative Commons Attribution (CC BY) license (http://creativecommons.org/licenses/by/4.0/). 